\title{
Mexican Coastal Dunes: Recipients and Donors of Alien Flora
}

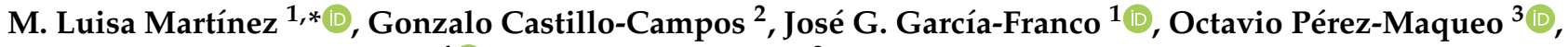 \\ Gabriela Mendoza-González ${ }^{4}$ (i) and J. Jesús Pale-Pale ${ }^{2}$ \\ 1 Red de Ecología Funcional, Instituto de Ecología, A.C. (INECOL), Xalapa 91073, Mexico; \\ jose.garcia.franco@inecol.mx \\ 2 Red de Biodiversidad y Sistemática, Instituto de Ecología, A.C. (INECOL), Xalapa 91073, Mexico; \\ gonzalo.castillo@inecol.mx (G.C.-C.); pale.33@hotmail.com (J.J.P.-P.) \\ 3 Red de Ambiente y Sustentabilidad, Instituto de Ecología, A.C. (INECOL), Xalapa 91073, Mexico; \\ octavio.maqueo@inecol.mx \\ 4 CONACYT-Facultad de Ciencias, UMDI-Sisal, Universidad Nacional Autónoma de México, \\ Sierra Papacal 97302, Mexico; gabriela.mendoza@ciencias.unam.mx \\ * Correspondence: marisa.martinez@inecol.mx
}

check for updates

Citation: Martínez, M.L.; Castillo-Campos, G.; García-Franco, J.G.; Pérez-Maqueo, O.;

Mendoza-González, G.; Pale-Pale, J.J. Mexican Coastal Dunes: Recipients and Donors of Alien Flora. Diversity 2021, 13, 530. https://doi.org/ $10.3390 / \mathrm{d} 13110530$

Academic Editor: Anatoliy A Khapugin

Received: 1 October 2021

Accepted: 21 October 2021

Published: 25 October 2021

Publisher's Note: MDPI stays neutral with regard to jurisdictional claims in published maps and institutional affiliations.

Copyright: (c) 2021 by the authors. Licensee MDPI, Basel, Switzerland. This article is an open access article distributed under the terms and conditions of the Creative Commons Attribution (CC BY) license (https:/ / creativecommons.org/licenses/by/ $4.0 /)$.

\begin{abstract}
The invasion of natural communities by exotic plants, which may turn into invasive or potentially invasive, is one of the most severe known threats to biodiversity, and coastal dunes are among the most affected habitats. Mexico's coastal dunes are abundant and contain high plant biodiversity but attempts to determine the occurrence and impact of exotic plants are absent. First, we explored the number of invasive plant species found on Mexican coastal dunes. Second, we analyzed if the coastal dune flora native from Mexico acts as a source of invasive species worldwide. We found the relevant spread of exotic plants towards and from Mexico, reaching high percentages: $5 \%$ of the coastal dune flora are considered exotic plants; this increases to $8.7 \%$ when only plants typical of the coastal dune environment are considered. The Mexican coastal dunes flora is also a relevant source of invasive plants affecting all continents. Furthermore, almost half of the 35 worst worldwide invasive plants (according to the Global Invasive Species Database GISD) grow on Mexican coastal dunes, most native to Mexico and invasive elsewhere. Indeed, the worldwide exchange of coastal dune flora between Mexico and the world seems massive, relevant and highlights the need for worldwide and countrywide management and control strategies.
\end{abstract}

Keywords: exotic plants; plant invasion; coastal dunes; Mexico; native

\section{Introduction}

Mexico is a megadiverse country because it hosts between 10 and 15\% of the planet's biodiversity in its territory, which only represents $1.4 \%$ of the total surface of the Earth $[1,2]$. The country is fifth worldwide in terms of the number of plant species [2]. Additionally, the country harbors the second largest diversity of ecosystems anywhere $[1,3]$.

Among the many ecosystems found on Mexican territory, coastal dunes are widespread, occurring throughout its $11,000 \mathrm{~km}$ of coasts. Recent estimates of the extension of coastal dunes performed by Martínez et al. [4] reveal that they cover 800,000 ha, representing $0.04 \%$ of the country. Nevertheless, because of their topographic heterogeneity, variability in weather regimes, and diversity of vegetation types, coastal dunes host 2072 plant species [5] which corresponds to $9.4 \%$ of the Mexican flora. This high percentage highlights the relevance of coastal dunes for Mexico's biodiversity. Furthermore, coastal dunes and accompanying plants provide relevant ecosystem services to society, such as mitigation of storm impacts, since they help reduce wave-induced erosion by as much as 64\% [6]. Additional ecosystem services provided by coastal dunes include scenic beauty, recreation, coastal protection, tourism, and habitat provision, among others, all appreciated by society [7]. Nevertheless, despite the relevance of coastal dunes, this ecosystem has been generally neglected in Mexico. Although some regions, such as the Gulf of Mexico and 
Caribbean, are relatively well known, other areas (i.e., the South Pacific) remain largely understudied [8].

The massive spread of species from areas outside their native ranges [9] threatens coastal dunes in Mexico and elsewhere. A few of them overcome the biotic and abiotic barriers of their new environment and become invasive. As they reproduce successfully and spread over large areas and long distances, their dominance increases, causing considerable impacts on plant diversity, wildlife, and ecosystem functioning [10]. Consequently, the highly specialized coastal dune flora, with many narrow-niched species, can be seriously endangered by biological invasions. Indeed, the invasion of natural communities by introduced (or alien) plants, which may turn into invasive or potentially invasive is one of the most severe known threats to biodiversity [11,12]. The attempts to determine the occurrence and impact of exotic plants in Mexico are scarce (e.g., [13,14]). Recently, Villaseñor and Espinosa-García [15] estimated that the proportion of exotic plants relative to the 22,968 native flowering plant species recorded for Mexico is $2.7 \%$, most of them having their origin in the Old World (Europe, Africa, and Asia). Additionally, RamírezAlbores et al. [16] explored the scientific literature regarding invasive species in Mexico and found a bias towards studies focused on natural history, geographic distribution patterns, and impacts on the native biota. However, how many exotic plants grow in the different ecosystems found in Mexico, where they come from, or their detailed distribution in the country remains uncertain.

Studies of species invasions on coastal dunes are manifold and include different countries. They reveal severe impacts on native communities. Examples of these are the genus Acacia in Europe [17]; Ammophila arenaria in South Africa [18]; Carpobrotus edulis in Portugal [19]; Oenothera drummondii in Spain [20] and even worldwide species invasions [21,22]. In Mexico, however, only four studies explore the occurrence of exotic plants on coastal dunes. Castillo and Moreno-Casasola [23] and Parra-Tabla et al. [24] acknowledge the susceptibility of coastal dunes to species invasions. Furthermore, CastilloCampos et al. [25] reported one new invasive plant, "beach naupaka" (sea-lettuce in Mexico) (Scaevola taccada), on the island of Cozumel, while its impact on the native flora was studied recently [26].

To our knowledge, the distribution of exotic plants on coastal dunes has not been addressed for Mexico, nor has their origin. It is also unknown if the Mexican native coastal dunes flora "exports" invasive plants to other countries. Consequently, the goals of this study were twofold. First, we aimed at exploring the number of plant species found on coastal dunes that are known as invasive or potentially invasive in Mexico. Second, because of the widespread movement of biota worldwide, we also wanted to analyze if the coastal dunes flora native from Mexico acts as a source of invasive species worldwide. We addressed the following questions: (a) how many (and which) invasive species are found on Mexican coastal dunes? (b) what is the level of invasion (number and abundance of species) across the coastal dunes of Mexico? (c) how many (and which) invasive species native to Mexican coastal dunes are considered invasives on coastal dunes worldwide? (d) what geographic invasion trajectories do invasive species follow from donor to recipient areas towards and from Mexico?

We first considered the geographic distribution patterns of exotic plants found on Mexican coastal dunes to answer these questions. Then, we explored if Mexican native coastal dunes species were reported to act as invasives elsewhere. Based on previous knowledge, we postulated specific expectations for our questions. First, given Mexico's countrywide high biodiversity, we hypothesized that native invasive plants of Mexican origin would outnumber invasives from abroad. Second, because of the ecological variability of coastal dune habitats and climatic regions in Mexico and the varying human impacts, we expected to observe contrasting levels of invasion in different biogeographical regions. Thus, we anticipated little overlap of invasive species across regions. Our results show that invasive species are widespread both in Mexico and from Mexico towards coastal dunes abroad, highlighting the need for global and national management and control measures. 


\section{Materials and Methods}

\subsection{Species Lists and Databases}

We combined several extensive plant species lists from Mexican coastal dunes, alien plants in Mexico, and alien-invasive species lists from different countries (Figure 1).

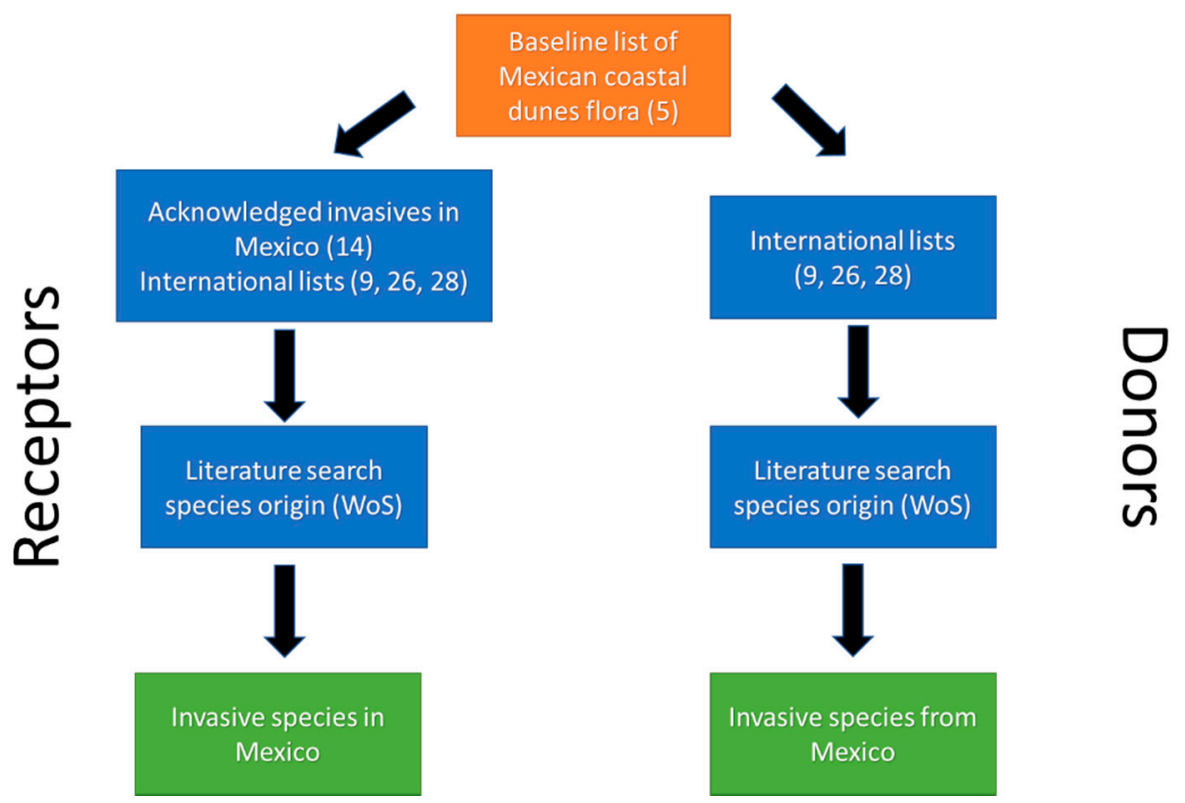

Figure 1. Combination of floristic lists and databases to elaborate a single list of invasive species on Mexican coastal dunes both as recipients (invasive in Mexico) and donors (native Mexican, invasive elsewhere). Numbers in parenthesis indicate the references from where information was gathered to perform the analyses.

To elaborate the list of invasive plants that grow on Mexican coastal dunes, we used the flora by Espejel et al. [5] as a baseline with which we compared the other lists that we reviewed. Their list includes species typical of the beach and coastal dunes and species that grow in other ecosystems that develop on coastal dunes, such as grasslands, scrubs, and forests. We focused on those species considered as typical from coastal dunes. Then, we compared this list with that of alien flowering plants of Mexico [15] and selected those species considered as either invasive or potentially invasive, which also belonged to the Mexican coastal dune flora. Additionally, we compared our baseline list with other invasive plant species lists, such as Oviedo-Prieto et al. [27], Giulio et al. [9], and the GISD [28]. Once we had this list of acknowledged exotic plants growing on Mexican coastal dunes, we searched the literature using the Web of Science to determine the geographic origin of each.

We followed a similar procedure to determine how many (and which) invasive species native to Mexican coastal dunes are considered invasives on coastal dunes worldwide (Figure 1). Again, we compared our baseline list with other invasive plant species lists $[5,9,28]$. We then searched the literature (Web of Science) to determine the geographic origin of each invasive or potentially invasive plant included in our list.

\subsection{Data Analyses}

The database with georeferenced presence records was built from different open access sources: National System of Information on Biodiversity [29], the Project "Flora of the beaches and coastal dunes of Mexico" [30], updated by [5] and the database of EncicloVida [31].

Based on this information, the geographic distribution of the species identified as invasive was projected in the coastal dunes of Mexico. Then, we elaborated individual maps with the presence records where each species was observed on the country's coasts. 
A table with the number of occurrence records was built to detect the coasts most vulnerable to species invasions in Mexico.

We then generated Sankey diagrams [32], which are flow diagrams in which the width of the arrows is proportional to the flow rate. This was useful for analyzing the number and abundance of invasive plants from each donor region towards the recipient areas (see Figure 1 for detailed explanation of the references and databases used). Sankey diagrams also helped identify the most important contributions to a flow; in our case, they helped find the regions where most species are donated and the regions where most species are received.

Finally, we performed a cluster analysis (UPGMA-unweighted pair group method with arithmetic mean) to determine the similarities between coastal states regarding the occurrence and abundance of invasive species. The UPGMA algorithm builds a rooted tree (dendrogram) that reflects the structure based on a pairwise distance matrix [33]. We used the Jaccard similarity index with the number of observations per species per state. The Jaccard similarity index measures similarity between finite sample sets [34]. It is defined as the size of the intersection divided by the size of the union of the sample sets:

$$
J(A, B)=\frac{|A \cap B|}{|A \cup B|}=\frac{|A \cap B|}{|A|+|B|-|A \cap B|}
$$

With this, we were able to identify the regions that were most sensitive to species invasions. We used the statistical package MVSP V 3.1 to perform this analysis and used species presence-absence data.

\section{Results}

In Mexico, the number of plant species found on coastal dunes is relatively large (Table 1). However, plant species typical of the coastal dunes environment are scarce, representing less than $1 \%$ of the floristic list reported by Espejel et al. [5]. (Table 1). Exotic plants appear to be relevant in the Mexican flora, representing 2.6\% of the Mexican flora, and $5 \%$ of the coastal dune flora. This percentage increases drastically to $8.7 \%$ when only plant species typical of the coastal dune environment (103) and the number of invasive plants are considered (9). The number of Mexican native species which are invading coastal dunes abroad is relatively large and represents $1.5 \%$ of the complete Mexican coastal dune flora (Table 1).

The list in the Global Invasive Species Database reports 35 plants among the 100 worst global invasive species (GISD—http:/ / www.iucngisd.org/gisd/100_worst.php (accessed on 17 July 2021). Of these, 13 plants are found in the Mexican coastal dune flora; one is invasive in Mexico, and the remaining 12 are native to Mexico, invasive elsewhere (Table 1).

Herbs are the most frequent exotic plants, both arriving at and leaving Mexico (Table 2), followed by trees and shrubs. The origin and destination of these plants are widespread and cover all continents, showing the vast biotic exchange taking place in coastal dune flora. Interestingly, no European plant was determined as invasive in Mexican coastal dunes, although many are considered potentially invasive (Table 2).

Invasive plants on Mexican coastal dunes belong to 10 families, with Poaceae being the most frequent (Table 3). Asia and Africa are the most frequent origins. In contrast with the above, the number of plant species native from Mexico and invasive abroad is much larger, adding a total of 30 species, which belong to 14 families. Fabaceae and Asteraceae contain the largest numbers of invasive plants ( 8 and 6 , respectively), while Poaceae are relatively scarce (3) (Table 4). All continents are recipients of these plants, primarily herbs (14 species) and shrubs (9), although some climbers and trees are also invasive. 
Table 1. Flora of Mexican coastal dunes and occurrence of exotic plants.

\begin{tabular}{|c|c|c|}
\hline Category & Number of Species & Reference \\
\hline \multicolumn{3}{|l|}{ Plant species richness } \\
\hline Native flowering plants recorded in Mexico & 22,968 & [15] \\
\hline Species included in the coastal dune flora of Mexico & 2072 & [5] \\
\hline Species typical of beach and coastal dunes of Mexico & 103 & [5] \\
\hline \multicolumn{3}{|l|}{ Exotic plants } \\
\hline Alien flowering plants in Mexico & 618 & [15] \\
\hline $\begin{array}{l}\text { Alien flowering plants found within the coastal dune flora } \\
\text { (potentially invasive) }\end{array}$ & 100 & [15] \\
\hline Invasive species growing on coastal dunes & 9 & {$[5,25]$; see Table 3} \\
\hline Mexican native species invading coastal dunes abroad & 30 & [5]; see Table 4 \\
\hline \multicolumn{3}{|l|}{100 worst global invasive species } \\
\hline Plant species & 35 & [28] \\
\hline Plants species found on Mexican coastal dunes & 13 & {$[28]$} \\
\hline Plant species determined as invasive on Mexican coastal dunes & 1 & [28] \\
\hline Plant species native in Mexico, invasive abroad & 12 & [28] \\
\hline
\end{tabular}

Table 2. Mexican coastal dunes: donors and recipients of invasive flora. In parenthesis, the number of species in each region. When the origin included different regions, they were listed in each, thus, numbers in parenthesis may add more than the total.

\begin{tabular}{|c|c|c|c|c|c|c|}
\hline Status & Total & Herbs & Shrubs & Trees & Vines & Origin/Destination \\
\hline $\begin{array}{c}\text { Invasive in } \\
\text { Mexico }\end{array}$ & 9 & 5 & 1 & 2 & 1 & Asia (4), Asia/Africa (3), Mediterranean (1), Africa (1) \\
\hline $\begin{array}{l}\text { Potentially } \\
\text { invasive in } \\
\text { Mexico }\end{array}$ & 100 & 84 & 6 & 6 & 4 & $\begin{array}{c}\text { Asia (19), Africa (18), Mediterranean (18), Europe/Asia } \\
\text { (10), Europe (8), South America (8), Asia / Africa (5), } \\
\text { Oceania (4), North America (4), Europe/Asia/Africa (3), } \\
\text { Caribbean (2), Europe/Africa (1) }\end{array}$ \\
\hline $\begin{array}{l}\text { Native in } \\
\text { Mexico/invasive } \\
\text { abroad }\end{array}$ & 30 & 14 & 9 & 3 & 4 & $\begin{array}{c}\text { Asia (5), Africa (1), Asia/Africa (2), } \\
\text { Asia/Africa/Oceania (4), Europe (2), Europe/Africa (2), } \\
\text { Europe/Asia/Africa (2), Oceania (2), } \\
\text { Europe/Oceania / Africa (2), Asia/Oceania (2), } \\
\text { Pantropical (2), North-South America / Asia (1), } \\
\text { Caribbean (1), Africa/Caribbean/North America (1), } \\
\text { Europe/Caribbean/Oceania (1), Africa/Asia/South } \\
\text { America (1) }\end{array}$ \\
\hline
\end{tabular}

Table 3. List of exotic plants found on Mexican coastal dunes. Abundant and potentially invasive plants $\left(^{*}\right)$.

\begin{tabular}{|c|c|c|c|c|c|}
\hline Invasive Species & Family & Top 100 & Origin & Growth Form & References \\
\hline Arundo donax $\mathrm{L}$. & Poaceae & Yes & Asia & Herb & [28] \\
\hline Calotropis procera (Aiton) W.T. Aiton & Apocynaceae & & Africa/Asia & Tree & [35] \\
\hline Cassytha filiformis L. & Lauraceae & & Asia & Parasitic & [24] \\
\hline Casuarina equisetifolia L. $\left({ }^{*}\right)$ & Casuarinaceae & & Oceania & Tree & {$[27]$} \\
\hline Cenchrus ciliaris L. & Poaceae & & Africa/Asia & Herb & {$[15,35,36]$} \\
\hline Cocos nucifera L. $\left(^{*}\right)$ & Arecaceae & & Asia/Oceania & Tree & [27] \\
\hline Eragrostis ciliaris (L.) R. Br. & Poaceae & & Africa/Asia & Herb & [35] \\
\hline Hirschfeldia incana (L.) Lagr.-Fossat & Brassicaceae & & Mediterraneum & Herb & {$[35,37]$} \\
\hline Oeceoclades maculata (Lindl.) Lindl. & Orchidaceae & & Africa & Herb & [35] \\
\hline Scaevola taccada (Gaertn.) Roxb. & Goodeniaceae & & Asia & Shrub & [25] \\
\hline Tamarix ramosissima Ledeb. & Tamaricaceae & Yes & Asia & Tree & {$[15,28,35]$} \\
\hline Terminalia catappa L. $\left({ }^{*}\right)$ & Combretaceae & & Asia & Tree & [38] \\
\hline
\end{tabular}


Table 4. List of plant species native to Mexico, found on coastal dunes, and considered invasive abroad. Top 100 from GISD [28] * Species typical of Mexican coastal dunes.

\begin{tabular}{|c|c|c|c|c|c|}
\hline Species & Family & Top 100 & Distribution & Growth Form & References \\
\hline Amaranthus spinosus $\mathrm{L}$. & Amaranthaceae & & $\begin{array}{l}\text { Europe/Asia/Africa } \\
\text { South Amer- }\end{array}$ & Herb & [39] \\
\hline Antigonon leptopus Hook. and Arn. & Polygonaceae & Yes & $\begin{array}{l}\text { ica/Asia/North } \\
\text { America }\end{array}$ & Climber & {$[24,28]$} \\
\hline Asclepias curassavica L. & Apocynaceae & & Pantropical & Herb & [37] \\
\hline Bidens pilosa $\mathrm{L}$. & Asteraceae & Yes & Europe/Asia/Africa & Herb & [24] \\
\hline Borrichia frutescens (L.) DC. * & Asteraceae & & Europe & Herb & [31] \\
\hline Caesalpinia bonduc (L.) Roxb. * & Fabaceae & & Caribbean & Shrub & [27] \\
\hline Cecropia peltata $\mathrm{L}$. & Urticaceae & Yes & Asia & Tree & [28] \\
\hline Centrosema virginianum (L.) Benth. & Fabaceae & & Asia/Africa/Oceania & Climber & [24] \\
\hline $\begin{array}{l}\text { Chromolaena odorata (L.) R.M. King and H. } \\
\text { Rob. }\end{array}$ & Asteraceae & Yes & Asia & Shrub & {$[28]$} \\
\hline Clidemia hirta (L.) D. Don & Melastomataceae & Yes & Asia & Shrub & [28] \\
\hline Datura stramonium L. & Solanaceae & & $\begin{array}{l}\text { North } \\
\text { America/Europe }\end{array}$ & Herb & [40] \\
\hline Desmodium tortuosum (Sw.) DC. & Fabaceae & & Pantropical & Herb & [41] \\
\hline Eragrostis prolifera (Sw.) Steud. * & Poaceae & & Europe/Africa & Herb & [42] \\
\hline Lantana camara L. & Verbenaceae & Yes & Asia/Africa & Shrub & [28] \\
\hline Lantana involucrata $\mathrm{L}$. & Verbernaceae & & Asia & Herb & [24] \\
\hline Leucaena leucocephala (Lam.) De Wit & Fabaceae & Yes & Asia/Africa & Tree & [28] \\
\hline Melanthera nivea (L.) Small & Asteraceae & & Asia & Herb & [24] \\
\hline Mikania micrantha Kunth & Asteraceae & Yes & Asia/Oceania & Climber & {$[24,28]$} \\
\hline Mimosa pigra L. & Fabaceae & Yes & Asia/Africa/Oceania & Shrub & {$[28]$} \\
\hline Oenothera drummondii Hook. * & Onagraceae & & Europe/Oceania/Africa & Herb & [9] \\
\hline Opuntia stricta (Haw.) Haw. & Cactaceae & Yes & Europe/Africa/Oceania & Shrub & [28] \\
\hline Passiflora foetida $\mathrm{L}$. & Passifloraceae & Yes & Oceania/Asia & Climber & {$[24,28]$} \\
\hline Pithecellobium dulce (Roxb.) Benth. & Fabaceae & & Africa & Tree & [43] \\
\hline Porophyllum punctatum (Mill.) S. F. Blake & Asteraceae & & Europe & Herb & [24] \\
\hline Prosopis glandulosa Torr. & Fabaceae & Yes & Asia/Africa/Oceania & Shrub & [28] \\
\hline Senna occidentalis (L.) Link & Fabaceae & & Asia/Africa/Oceania & Herb & [44] \\
\hline Solanum erianthum D. Don & Solanaceae & & Oceania & Shrub & [45] \\
\hline Sporobolus indicus (L.) R. Br. * & Poaceae & & $\begin{array}{c}\text { Europe, Caribbean, } \\
\text { Oceania, North } \\
\text { America }\end{array}$ & Herb & [27] \\
\hline Sporobolus jacquemontii Kunth & Poaceae & & Oceania & Herb & [15] \\
\hline Tecoma stans (L.) Juss. ex Kunth & Bignoniaceae & & $\begin{array}{c}\text { Africa/Asia/South } \\
\text { America }\end{array}$ & Shrub & [46] \\
\hline
\end{tabular}

The flow of exotic plants from and towards Mexico is broad and includes all continents (Figure 2). Mexican native plants considered invasives abroad have reached all regions, except for the Mediterranean. In turn, potentially invasive plants found on Mexican coastal dunes have arrived from all regions (Asia, Africa, and the Mediterranean), but not from Europe, North or South America, and the Caribbean.

The nine exotic plants considered invasive on coastal dunes (Figure 3) are widespread throughout the Mexican coasts (Figure 4), although there are differences between species: some are more extensive while others have a narrow distribution. For instance, the three Poaceae (Arundo donax, Cenchrus ciliaris, and Eragrostis ciliaris), all of Asian and African origin, are found on almost all coasts. The two peninsulas concentrate on different invasive species. Hirschfeldia incana (herb of Mediterranean origin) and Tamarix ramossisima (tree of Asian origin) are found in the northwestern Baja California region. In contrast, four invasive plants occur in the Yucatan peninsula, in the southeast: Cassytha fifliformis (creeper from Asia), Calotropis procera (tree from Africa/Asia), Oeceoclades maculata (herb from Africa), and Scaevola taccada (shrub from Asia). 


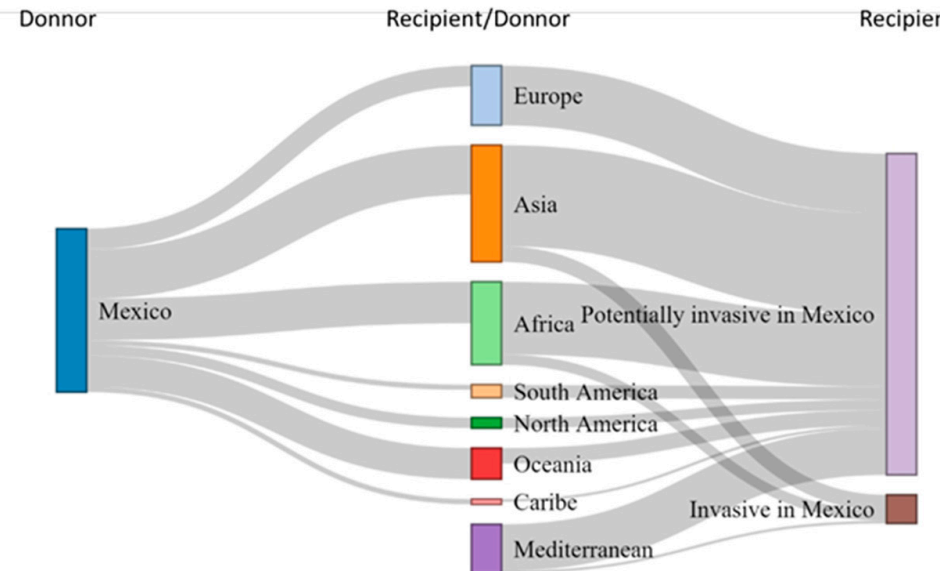

Figure 2. Sankey diagram showing the number of exotic plants from each donor region flowing from and towards Mexico.

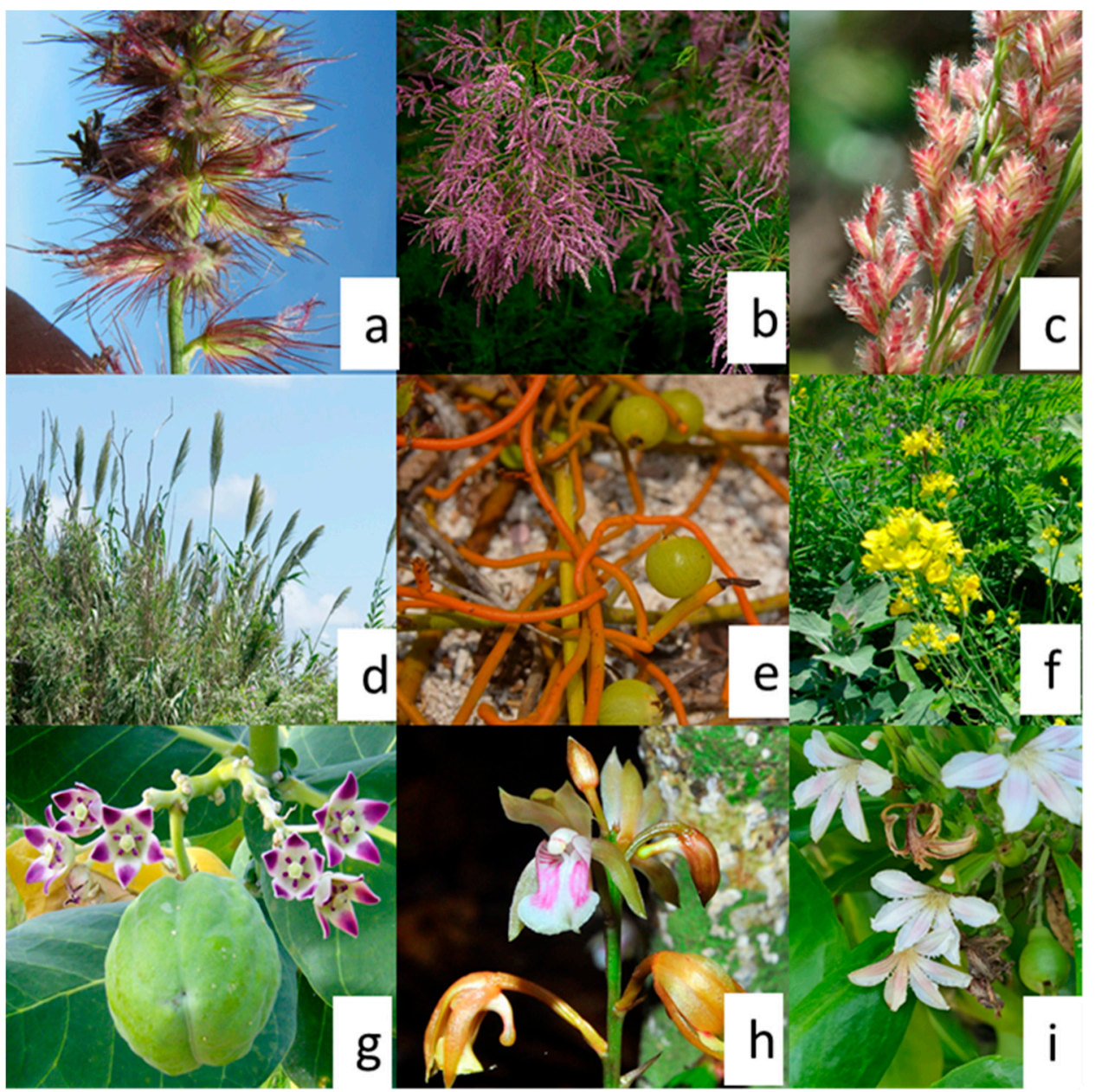

Figure 3. Invasive species found on Mexican coastal dunes. (a) Cenchrus ciliaris (Flickr); (b) Tamarix ramosissima ((PxFuel); (c) Eragrostis ciliaris (Naturalista); (d) Arundo donax (Naturalista); (e) Cassytha filiformis (Donaji Graham, Naturalista); (f) Hirschfeldia incana (Flickr); (g) Calotropis procera (Naturalista); (h) Oeceoclades maculata (Flickr) (i) Scaevola taccada (M. Luisa Martínez). Picture credits are in parenthesis after the name of each species. 


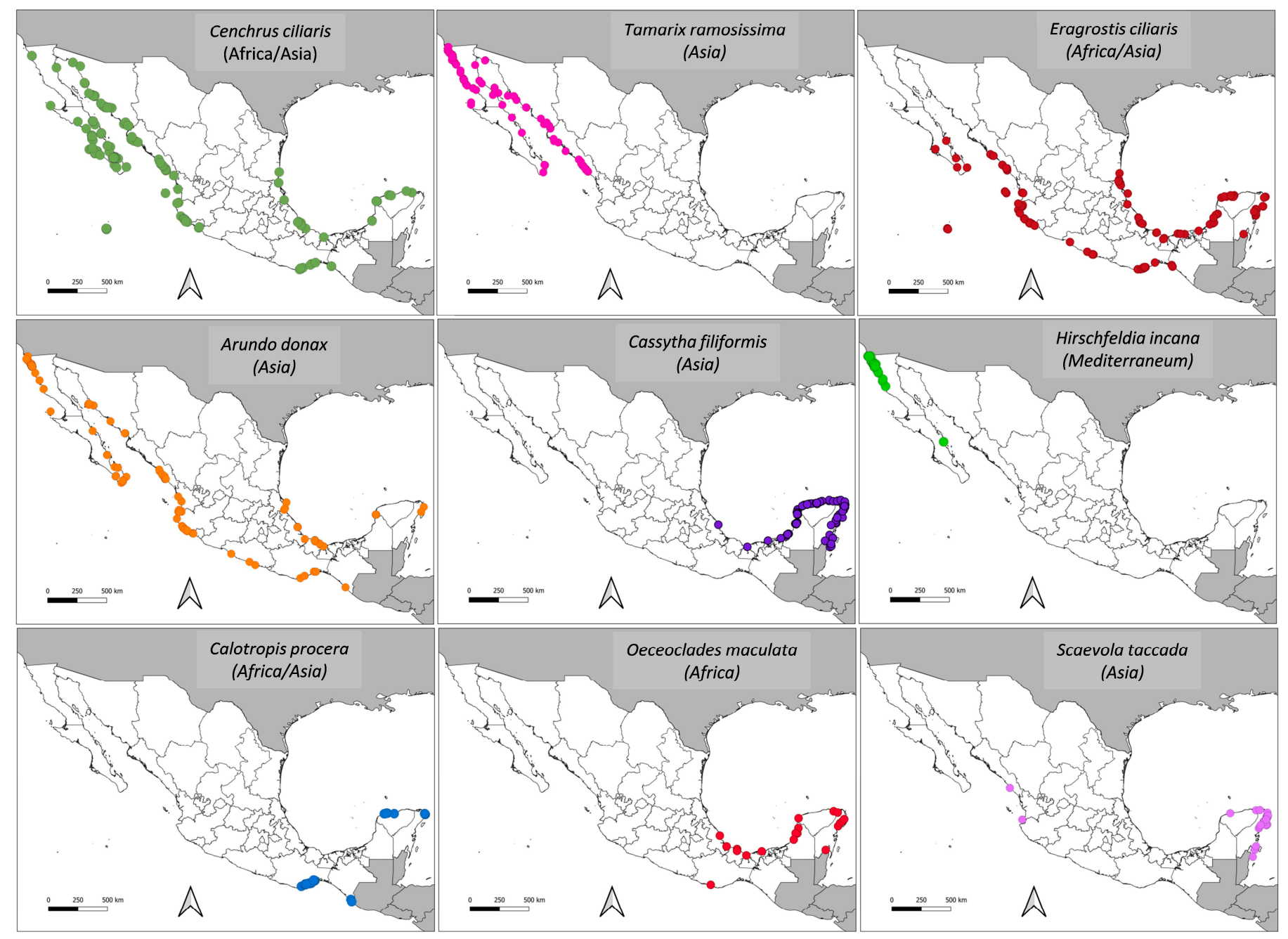

Figure 4. Geographic distribution and origin of the acknowledged invasive plant species found on Mexican coastal dunes. Maps elaborated by the authors using information from National System of Information on Biodiversity [29], the Project "Flora of the beaches and coastal dunes of Mexico" [30], updated by [5] and the database of EncicloVida [31].

The number of records of each invasive plant is also variable (Figure 5), with Cenchrus ciliaris, Tamarix ramosissima, Eragrostis ciliaris, and Arundo donax being the ones most frequently observed. Scaevola taccada has the least number of reported observations. The combined distribution of all invasive species shows that they cover most of the coasts of Mexico (Figure 6), except for the north of the Gulf of Mexico and the South Pacific, where studies on coastal dunes are scarcer.

Finally, we combined the number of species and observations to determine those areas that are most vulnerable to species invasion (Figure 7). The two peninsulas, Baja California, and Yucatán contain the largest number of records and the highest number of species. The states of Veracruz and Oaxaca also have a relatively large number of records and species. The number of records and invasive species is smaller in the remaining coastal regions. The cluster analysis corroborates the trends observed in the map: the states from the Yucatan peninsula (Campeche, Yucatán, and Quintana Roo) and southeastern Gulf of Mexico (Veracruz and Tabasco) are grouped in one cluster, with the highest number of invasive species and incidence. The Baja California peninsula is grouped at the other extreme of the cluster, with many observations but fewer invasive species. All other states are grouped in the intermediate clusters. 


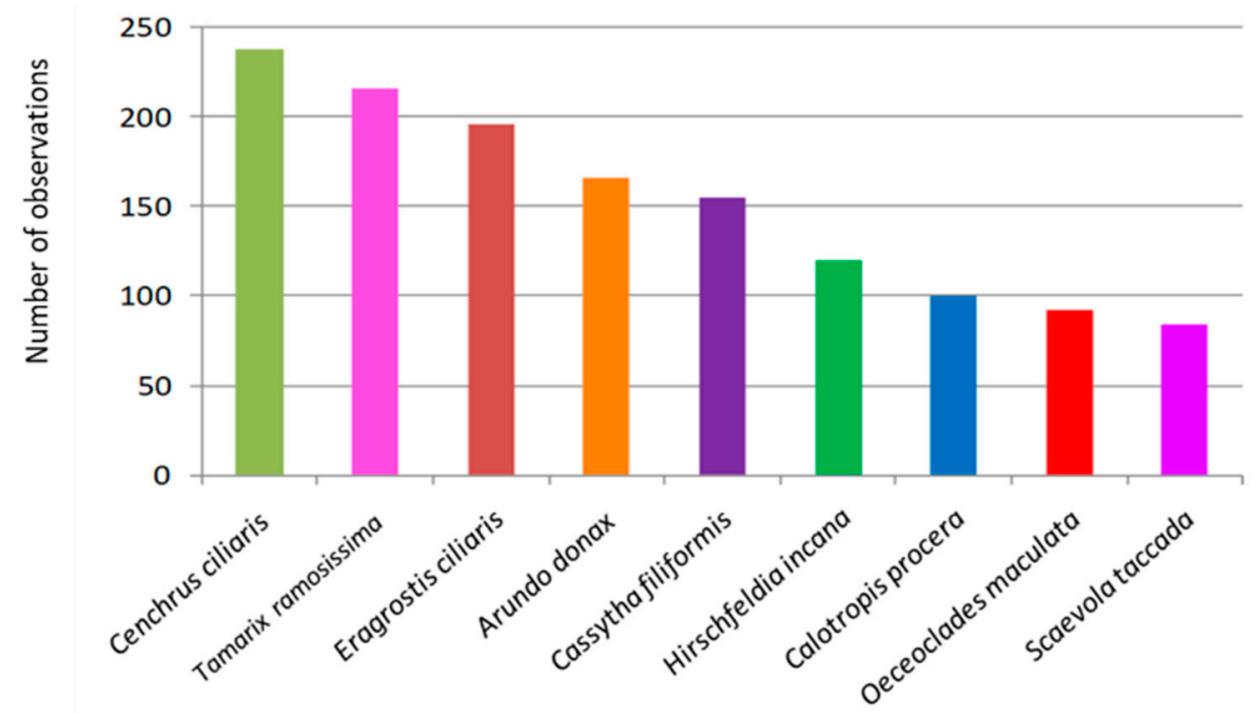

Figure 5. Number of observations of invasive species growing on coastal dunes.

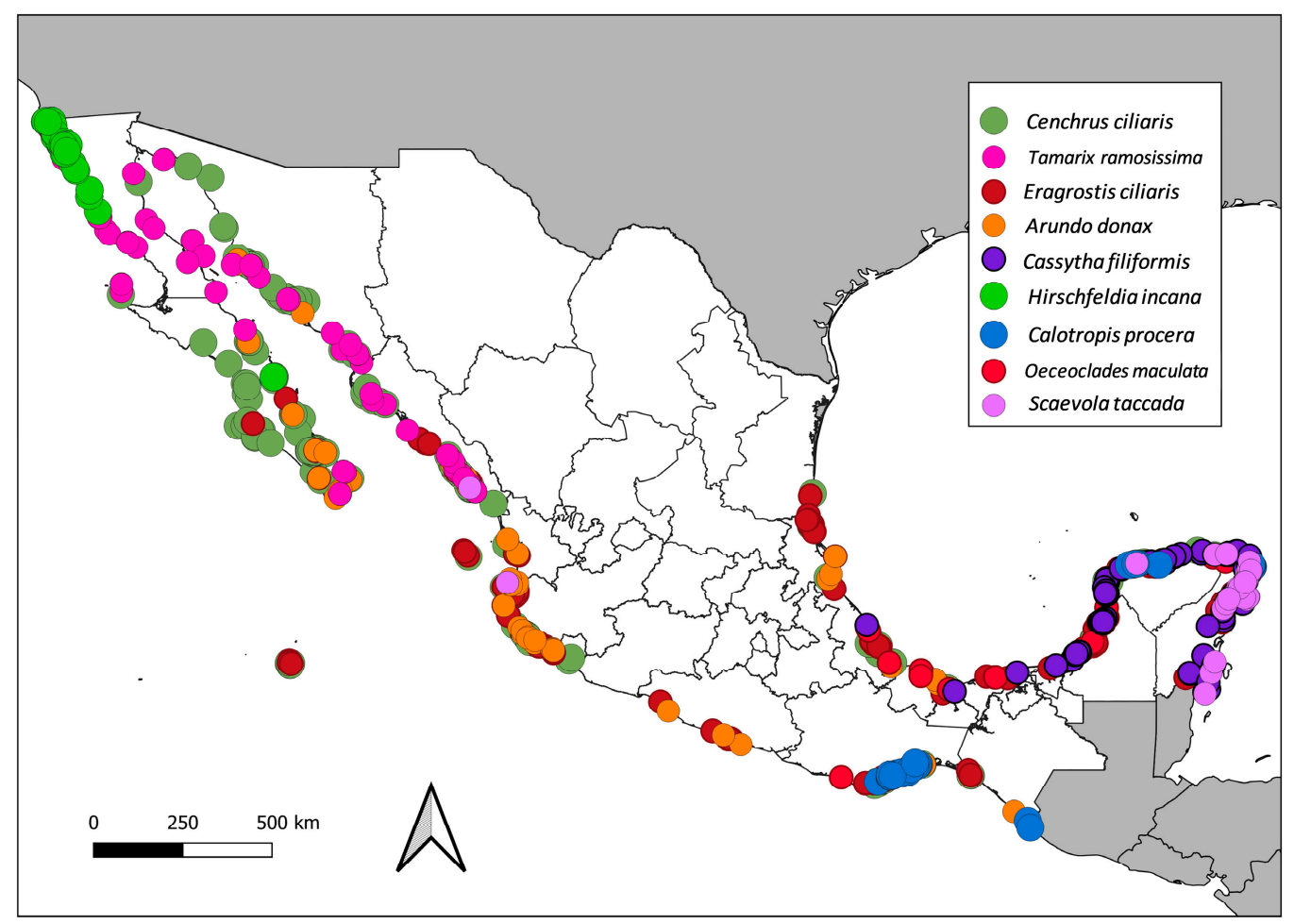

Figure 6. Combined geographic distribution of the nine exotic plants reported as invasive on Mexican coastal dunes.

These findings suggest three entry points (Figures 7 and 8). (1) Baja California and the northwestern region where Arundo donax, Cenchrus ciliaris, Hirschfeldia incana, and Tamarix ramosissima are abundant. (2) The second entry point is the Yucatan peninsula, including the southeastern Gulf of Mexico, with the dominance of Cassytha fifliformis, Calotropis procera, Oeceoclades maculata, and Scaevola taccada. (3) The third entry point is in the southern Pacific, mainly Oaxaca, where Eragrostis ciliaris abounds (Figures 7 and 8). 


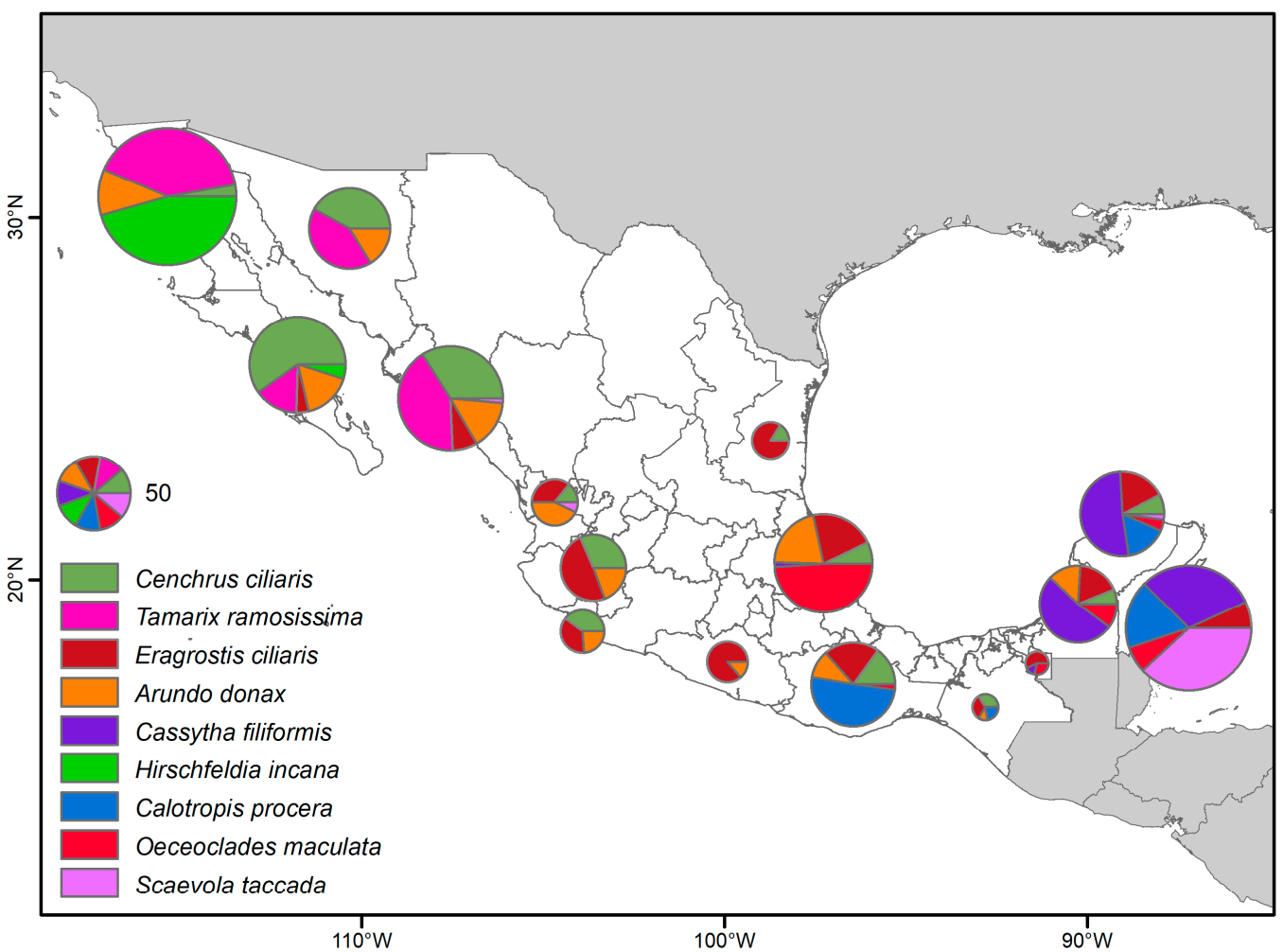

Figure 7. Distribution of invasive plant species throughout the coastal dunes of Mexico. The size of the pie chart indicates the total number of records per coastal state; each slice represents one invasive plant species, and its size is representative of the relative number of records of each.

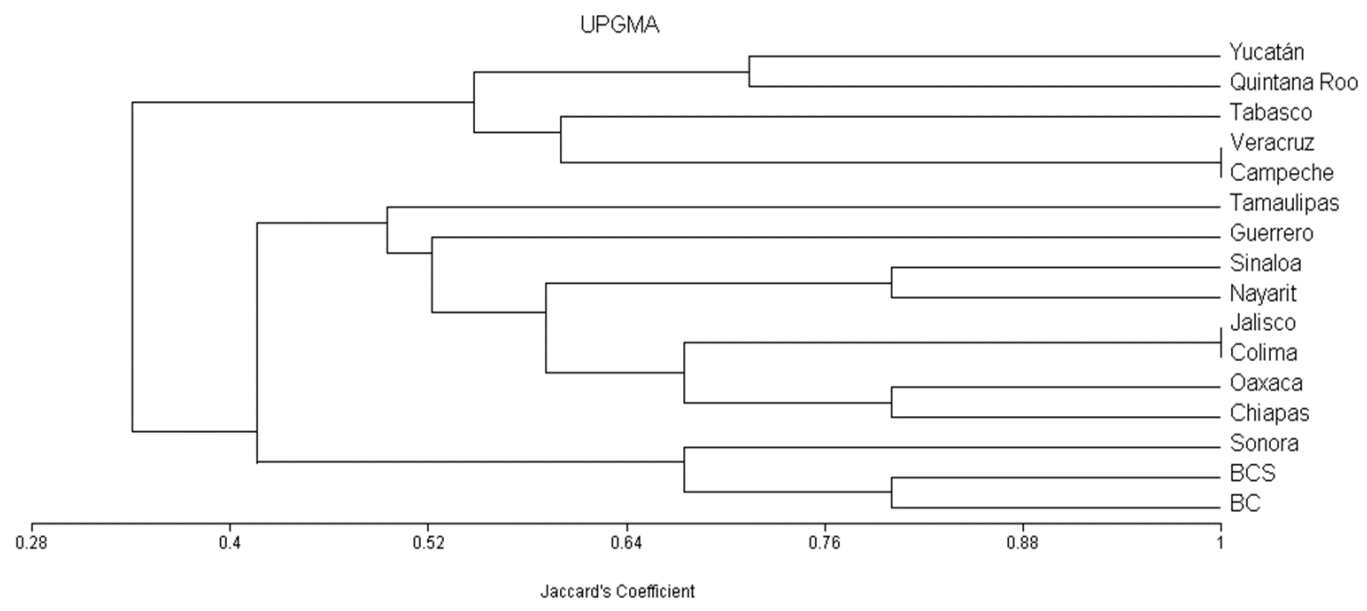

Figure 8. Cluster analysis in which the coastal states of Mexico are grouped according to the number of invasive plant species and frequency of observations.

\section{Discussion}

Our results show that exotic plants occur throughout the Mexican coasts and that the Mexican coastal dune flora is a relevant donor of invasive species abroad. Africa and Asia were the leading donors of invasive plants to Mexican dunes. In turn, all continents are recipients of invasive species from the Mexican coastal dunes, except for the Mediterranean.

The study is novel because it focused on the distribution of exotic plants on Mexican coastal dunes and their origin, which has not been carried out before. We also explored if the Mexican native coastal dune flora "exports" invasive plants to other countries. Our results indicate a relevant spread of exotic plants towards and from Mexico, reaching relatively high percentages. For instance, $5 \%$ of the coastal dune flora is considered exotic 
(invasive or potentially invasive). This percentage increases drastically to $8.7 \%$ when only plants typical of the coastal dune environment are considered. Similar values were obtained for the Mexican flora in which aliens represent $2.6 \%$ at a countrywide level [15], while Giulio et al. [9] report 7\% exotic plants for European coastal dunes. The high number of potentially invasive plants (101) found on Mexican coastal dunes needs to be paid close attention to, especially considering that these environments are highly vulnerable to species invasions $[9,23,24]$. At first, these species may seem innocuous or even beneficial, and few actually turn into invasives. However, the possibility of these exotic plants becoming invasive and harmful at a later stage cannot be overlooked [15].

The Mexican coastal dunes flora is a relevant source of invasive plants affecting all continents. Even though only $1.5 \%$ are invasive abroad, this represents many species (30) having a negative impact on different ecosystems, including coastal dunes. Furthermore, almost half of the 35 worst worldwide invasive plants grow on Mexican coastal dunes, most of them native to Mexico and invasive elsewhere. Indeed, the worldwide exchange of coastal dune flora between Mexico and the world seems massive and relevant. Thus, it is necessary for a much more detailed analysis.

\subsection{Mexican Coastal Dunes Flora as Donors vs. Recipient of Exotic Plants}

Our results are in accordance with our working hypothesis: we expected that, given Mexico's countrywide high biodiversity, invasive plants of Mexican origin would outnumber invasives from abroad arriving in Mexico. Indeed, the number of Mexican natives invading ecosystems abroad (30) more than tripled the number of invasive plants found on coastal dunes (9).

The possible reasons behind the differences in the number of invasive species imported and exported to and from Mexico are manifold and include ecological processes and socioeconomic circumstances. First, ecological processes determine the successful arrival and establishment of exotic plants. These can be affected by a broad array of factors, such as abiotic conditions, disturbance regimes, properties of the invasive species, and community structure $[47,48]$. Additionally, biological attributes of invading species and the numbers of individuals introduced, play a key role in successful invasions [49]. Consequently, some communities appear to resist invasions of exotic plants better than others [50], and the susceptibility of being invaded differs between biomes, ecosystems, and regions [11].

In accordance with the above, Dawson et al. [51], Pysek et al. [12] Lonsdale [11] and Gao et al. [52] found that temperate zones are more vulnerable to invasive species than tropical regions. Gao et al. [52] also observed that species from tropical areas invaded more easily than those from other climatic zones. Furthermore, De Roy et al. [47] demonstrated that community evenness was negatively correlated with invasibility more than diversity. The relative abundance of the species (evenness) was an essential factor that determined the vulnerability of a community to species invasion because of higher niche overlap and competition with decreasing evenness. In brief, communities with a low plant cover (such as temperate zones) may have more vacant niches with reduced competition and are more vulnerable to biological invasions [52] than tropical areas.

Socioeconomic conditions may also affect invasibility. Nuñez and Pauchard [53] and Frehse et al. [54] stated that, for instance, comparisons of biological invasions between developed and developing countries pose a difficult task because of differences in data quality and availability. McGeoch et al. [55] and Frehse et al. [54] concluded that alien species' number of documented invasions is significantly underestimated in developing countries because its value is affected by country development research effort and information availability.

Besides a reduced number of studies, it is also relevant to consider that an increased economic development enhances international trade and travel that transports alien species to new areas. Economic development also brings about road and building constructions that modify natural habitats, enhance the spread of invasive species, promote disturbance, 
intensify the loss of resistance from the local communities to the invasions, and thus, accelerate biological invasions [56].

It is thus possible that the differences observed between the number of invasive species arriving in or leaving from Mexico are associated with weather regimes, ecological processes, and socioeconomic conditions [56]. Global studies of naturalized alien flora [12] hardly show Mexican coasts with invasive plants, except for the Yucatan Peninsula, probably because of the reduced number of reported studies. Consequently, our findings highlight the need for more studies on biological invasions in tropical and megadiverse regions, generally located in developing countries. This is particularly relevant because environmental, economic, and societal negative impacts caused by the introduction of non-native species are often underestimated in megadiverse developing nations [54,57].

\subsection{High-Risk Areas of Exotic Plants Invasions in Mexican Coastal Dunes}

This study shows that the two peninsulas, Baja California and Yucatan, host the largest number of species and records. These trends are contrary to what is usually expected: communities richer in native and endemic species had more, not fewer, exotic plants [11]. Indeed, both peninsulas host the largest number of coastal dunes endemics. Endemic plants represent $26 \%$ of the native Baja California flora [51,52], while the Yucatan peninsula and the Gulf of Mexico rank second and third in terms of endemics [58] and [59] respectively. The positive relationship between native richness (and endemic species) and the degree of invasion is probably correlated with environmental heterogeneity and habitat diversity [11] This seems to apply to both peninsulas. For instance, the high number of endemic species in Baja California may be due to the variety of dune types and the combination of coastal dune and desert floras [4]. In turn, the mixture of coastal dune flora of the Yucatan peninsula with the coastal scrub and nearby tropical rainforest [4] enhances local diversity. In both cases, environmental heterogeneity and habitat diversity are probably underlying causes rendering the peninsulas rich in endemic species and susceptible to invasions. In addition to the above, the coasts in both peninsulas are also relevant sites for sea, sand, and sun tourism, promoting the arrival of exotic species.

\subsection{High-Risk Areas of Invasions with Exotic Plants in Mexican Coastal Dunes}

Our results show that the two peninsulas, Baja California and Yucatan, host the largest number of species and records. These trends are contrary to what is usually expected: communities richer in native and endemic species had more, not fewer, neophytes [11]. Indeed, both peninsulas host the largest number of coastal dunes endemics. Endemic plants represent $26 \%$ of the native Baja California flora $[4,60]$, while the Yucatan peninsula and the Gulf of Mexico rank second and third in terms of endemics [4] and [59] respectively. The positive relationship between native richness (and endemic species) and the degree of invasion is probably correlated with environmental heterogeneity and habitat diversity [11] This seems to apply to both peninsulas. For instance, the high number of endemic species in Baja California may be due to the variety of dune types and the combination of coastal dune and desert floras [4]. In turn, the mixture of coastal dune flora of the Yucatan peninsula with the coastal scrub and nearby tropical rainforest [4] enhances local diversity. In both cases, environmental heterogeneity and habitat diversity are probably underlying causes rendering the peninsulas rich in endemic species and susceptible to invasions. In addition to the above, the coasts in both peninsulas are also relevant sites for sea, sand, and sun tourism, promoting the arrival of exotic species.

\subsection{Purposes and Introduction Paths}

Indeed, global exchange and the accumulation of exotic plants are mostly linked to human activities. The high worldwide mobility of humans has eroded biogeographic barriers. Thus, human-mediated dispersal of species into new regions where they can become naturalized and cause ecological, economic, and social damage is becoming increasingly known and studied [61]. 
Knowledge of the dispersion mechanisms of species is fundamental to understanding how biological invasions take place. Biological invasions usually begin with long-distance dispersal, brought about either directly or indirectly by human action [62]. Nevertheless, vectors of introductions are still not assessed in important global reviews on invasions [54], and often, the paths followed by invasive species remain largely unknown.

There are two types of human activities that enforce the introduction of alien species: intentional introduction and unconscious or accidental introduction [52]. The former refers to those species that offer benefits to humans, and the latter involves the contamination of seeds in products intended for economic trade [52]. The nine invasive plants reported for Mexican coastal dunes seem to have followed a combination of routes. For instance, Oeceoclades maculata, Scaevola taccada, and Tamarix ramosissima were probably introduced as ornamental plants which later escaped from cultivation [26]; Cenchrus ciliaris and Eragrostis ciliaris are used for cattle grazing [36], and Arundo donax for erosion control [52]. Hirschfeldia incana probably arrived through contaminated products such as seed mixes, animal food, and agricultural crops [52]. The mechanisms for long-distance dispersal of Cassytha filiformis and Calotropis procera remain largely unknown. Indeed, international trade has contributed most to the dispersion of species beyond their natural range [63].

After long-distance dispersal, different processes are necessary for local dispersion. The dispersal of seeds and plant fragments and the regional expansion from the original point of introduction may take place through ocean currents $[25,64]$, which probably occurs with Arundo donax and Scaevola taccada (field observations). A secondary dispersal mechanism may occur through endozoochory (Scaevola taccada and Cassytha filiformis) which facilitates the expansion process at a local scale [64].

In brief, biological invasions are affected by complex ecological processes, environmental conditions, and socioeconomic situations. Consequently, holistic multidisciplinary approaches are urgently required to understand this phenomenon [56]. From this knowledge, specific control and management actions can be promoted.

\section{Conclusions}

This is the first comprehensive study exploring the distribution of exotic plants arriving at and leaving from Mexican coastal dunes and considering their origin and destination. Our results show that exotic plants occur throughout the Mexican coasts and that the coastal dune flora is a relevant donor of invasive species abroad. Africa and Asia were the leading donors of invasive plants to Mexican dunes, and no European invasive plants were recorded in Mexico. In turn, all continents are recipients of Mexican dune species, except for the Mediterranean. In Mexico, the levels of invasion differed regionally, and the areas with the highest number of endemic dune flora were also the ones with the highest number and abundance of invasives.

Overall, our results highlight that the dune habitats of a megadiverse country such as Mexico may be at risk from exotic species invasions. However, the number of scientific studies in this regard is relatively low. Consequently, the current knowledge aimed at predicting the potential impact of invasive species is still insufficient, and only general patterns were found. Thus, assessing the socio-economic and environmental impacts of invasive species observed on Mexican coastal dunes is necessary.

Our results suggest the need for invasion management plans at a national level because invasive plants are found throughout the coastal dunes of Mexico. Given the relevant exchange of species between coastal dune floras, it is necessary to produce a global agenda to deal with these invasions. These global strategies should focus on the rate of introduction, the number of invasive plants with major impacts, the extent of area affected by invasions, and adequate management actions.

Future studies regarding invasive and alien plants on Mexican coastal dunes could include estimating the potential distribution of each species, understanding dispersal mechanisms, and exploring control methods to prevent their growing expansion in the country. 
Author Contributions: Conceptualization, G.C.-C., J.G.G.-F. and M.L.M.; methodology, M.L.M.; G.C.-C. and J.G.G.-F.; formal analysis, G.C.-C., O.P.-M. and G.M.-G.; resources, M.L.M.; data curation, M.L.M. and J.J.P.-P.; writing-original draft preparation, M.L.M.; writing-review and editing, G.C.-C., J.G.G.-F., O.P.-M., G.M.-G. and J.J.P.-P.; visualization, G.M.-G.; project administration, M.L.M.; funding acquisition, M.L.M. All authors have read and agreed to the published version of the manuscript.

Funding: The present research was developed under the framework of CEMIE-Océano (Mexican Centre for Innovation in Ocean Energy), project FSE-2014-06-249795 financed by CONACYT-SENERSustentabilidad Energética.

Institutional Review Board Statement: Not applicable.

Data Availability Statement: This study used public databases.

Acknowledgments: We are very grateful to Rosario Landgrave for her help in producing Figure 7. Our gratitude also to the two anonymous reviewers and the editor who greatly helped us improve earlier versions of the text.

Conflicts of Interest: The authors declare no conflict of interest. The funders had no role in the design of the study; in the collection, analyses, or interpretation of data; in the writing of the manuscript, or in the decision to publish the results.

\section{References}

1. Jiménez-Sierra, C.L.; Sosa-Ramírez, J.; Cortés-Calva, P.; Solís-Cámara, A.B.; Íñiguez-Dávalos, L.I.; Ortega-Rubio, A. México país megadiverso y la relevancia de las áreas naturales protegidas. Investig. Cienc. 2014, 22, 16-22.

2. Llorente-Bousquets, J.; Ocegueda, S. Estado del conocimiento de la biota. In Capital natural de México, vol. I: Conocimiento actual de la biodiversidad; CONABIO: Mexico City, Mexico, 2008; Volume I, pp. 283-322. ISBN 978-607-7607-03-8.

3. Challenger, A.; Caballero, J. Utilización y Conservación de los Ecosistemas Terrestres de México: Pasado Presente y Futuro; CONABIOInstituto de Biología, UNAM-Agrupación Sierra Madre: Delegación Coyoacán, Mexcio, 1998.

4. Martínez, M.L.; Moreno-Casasola, P.; Espejel, I.; Jiménez-Orocio, O.; Infante-Mata, D.; Rodríguez-Revelo, N. Diagnóstico de las dunas costeras de México; CONAFOR: Guadalajara, Jalisco, 2014.

5. Espejel, I.; Jiménez-Orocio, O.; Castillo-Campos, G.; Garcillán, P.; Álvarez, L.; Castillo-Argüero, S.; Durán, R.; Ferrer, M.; Infante-Mata, D.; Iriarte, S.; et al. Flora en playas y dunas costeras de México. Acta Bot. Mex. 2017, 121, 39-81. [CrossRef]

6. Martínez, M.L.; Silva, R.; López-Portillo, J.; Feagin, R.A.; Martínez, E. Coastal ecosystems as an ecological membrane. J. Coast. Res. 2020, 95, 97-101. [CrossRef]

7. Mendoza-González, G.; Paredes-Chi, A.; Méndez-Funes, D.; Giraldo, M.; Torres-Irineo, E.; Arancibia, E.; Rioja-Nieto, R. Perceptions and social values regarding the ecosystem services of beaches and coastal dunes in Yucatán, México. Sustainability 2021, 13, 3592. [CrossRef]

8. Jiménez-Orocio, O.; Espejel, I.; Martínez, M.L. La investigación científica sobre dunas costeras de México: Origen, evolución y retos. Rev. Mex. Biodivers. 2015, 86, 486-507. [CrossRef]

9. Giulio, S.; Acosta, A.T.R.; Carboni, M.; Campos, J.A.; Chytrý, M.; Loidi, J.; Pergl, J.; Pyšek, P.; Isermann, M.; Janssen, J.A.M.; et al. Alien flora across European coastal dunes. Appl. Veg. Sci. 2020, 23, 317-327. [CrossRef]

10. Blackburn, T.M.; Bellard, C.; Ricciardi, A. Alien versus native species as drivers of recent extinctions. Front. Ecol. Evol. 2019, 17, 203-207. [CrossRef]

11. Lonsdale, W.M. Global patterns of plant invasions and the concept of invasibility. Ecology 1999, 80, 1522-1536. [CrossRef]

12. Pyšek, P.; Pergl, J.; Essl, F.; Lenzner, B.; Dawson, W.; Kreft, H.; Weigelt, P.; Winter, M.; Kartesz, J.; Nishino, M.; et al. Naturalized alien flora of the world: Species diversity, taxonomic and phylogenetic patterns, geographic distribution and global hotspots of plant invasion. Preslia 2017, 89, 203-274. [CrossRef]

13. Rzedowski, J.; Calderón de Rzedowski, G. Nota sobre el elemento africano en la flora adventicia de México. Acta Bot. Mex. 1990, 12, 21-24. [CrossRef]

14. Rzedowski, J. Diversidad y orígenes de la flora fanerogámica de México. Acta Bot. Mex. 1991, 14, 3-21. [CrossRef]

15. Villaseñor, J.L.; Espinosa-Garcia, F.J. The alien flowering plants of Mexico. Divers. Distrib. 2004, 10, 113-123. [CrossRef]

16. Ramírez-Albores, J.E.; Badano, E.I.; Flores, J.; Flores-Flores, J.L.; Yáñez-Espinosa, L. Scientific literature on invasive alien species in a megadiverse country: Advances and challenges in Mexico. NeoBiota 2019, 113-127. [CrossRef]

17. Lorenzo, P.; González, L.; Reigosa, M.J. The genus Acacia as invader: The characteristic case of Acacia dealbata Link in Europe. Ann. For. Sci. 2010, 67, 101. [CrossRef]

18. Hertling, U.M.; Lubke, R.A. Assessing the potential for biological invasion-The case of Ammophila arenaria in South Africa. S. Afr. J. Sci. 2000, 96, 520-527.

19. Souza-Alonso, P.; González, L. Don't leave me behind: Viability of vegetative propagules of the clonal invasive Carpobrotus edulis and implications for plant management. Biol. Invasions 2017, 19, 2171-2183. [CrossRef] 
20. Gallego-Fernández, J.B.; Martínez, M.L.; García-Franco, J.G.; Zunzunegui, M. The impact on plant communities of an invasive alien herb, Oenothera drummondii, varies along the beach-coastal dune gradient. Flora 2019, 260, 151466. [CrossRef]

21. Tordoni, E.; Bacaro, G.; Weigelt, P.; Cameletti, M.; Janssen, J.A.M.; Acosta, A.T.R.; Bagella, S.; Filigheddu, R.; Bergmeier, E.; Buckley, H.L.; et al. Disentangling native and alien plant diversity in coastal sand dune ecosystems worldwide. J. Veg. Sci. 2021, 32, 1-13. [CrossRef]

22. Tordoni, E.; Petruzzellis, F.; Nardini, A.; Savi, T.; Bacaro, G. Make it simpler: Alien species decrease functional diversity of coastal plant communities. J. Veg. Sci. 2019, 30, 498-509. [CrossRef]

23. Castillo, S.; Moreno-Casasola, P. Coastal sand dune vegetation: An extreme case of species invasion. J. Coast. Conserv. 1996, 2, 13-22. [CrossRef]

24. Parra-Tabla, V.; Albor-Pinto, C.; Tun-Garrido, J.; Angulo-Pérez, D.; Barajas, C.; Silveira, R.; Ortíz-Díaz, J.J.; Arceo-Gómez, G. Spatial patterns of species diversity in sand dune plant communities in Yucatan, Mexico: Importance of invasive species for species dominance patterns. Plant Ecol. Divers. 2018, 11, 157-172. [CrossRef]

25. Castillo-Campos, G.; García-Franco, J.G.; Martínez, M.L. First record of naturalization of Scaevola taccada (Gaert.) Roxb. (Goodeniaceae) in southern Mexico. BioInvasions Rec. 2021, 10, 425-435. [CrossRef]

26. Castillo-Campos, G.; Martínez, M.L.; Vázquez, G.; García-Franco, J.G.; Pérez-Maqueo, O.; Pale-Pale, J. Assessing the impact of an invasive plant in a Natural Protected Area: Island of Cozumel, Mexico. Biol. Invasions. 2018, 5, 180835.

27. Oviedo, R.; Herrera, P.; Caluff, M.G.; Regalado, L.; Ventosa, I.; Placencia, J.M.; González-Oliva, L. Lista nacional de especies de plantas invasoras y potencialmente invasoras en la República de Cuba. Plantas invasoras en Cuba. Bissea 2012, 6, 22-96.

28. Global Invasive Species Database. Available online: http:/ / www.iucngisd.org/gisd/100_worst.php (accessed on 14 May 2021).

29. CONABIO National System of Information on Biodiversity (SNIB: Sistema Nacional de Información sobre Biodiversidad). Available online: https:/ /www.snib.mx/ (accessed on 2 September 2021).

30. Espejel, I.; Jiménez-Orocio, O.; Peña-Garcillán, P. Flora de las playas y dunas costeras de México. Informe final SNIB-CONABIO, proyecto No. HJ007; CONABIO: Ensenada, Mexico, 2015.

31. CONABIO EncicloVida. Available online: http:/ / www.enciclovida.mx (accessed on 14 May 2021).

32. Schmidt, M. The Sankey Diagram in Energy and Material Flow Management. J. Ind. Ecol. 2008, 12, 173-185. [CrossRef]

33. Sokal, R.R.; Michener, C.D. A statistical method for evaluating systematic relationships. Univ. Kansas Sci. Bull. 1958, 38, 1409-1438.

34. Real, R.; Vargas, J.M. The Probabilistic Basis of Jaccard 's Index of Similarity. Syst. Biol. 1996, 45, 380-385. [CrossRef]

35. Mifsut, M.I.J.; Martinez, J.M. Especies invasoras de alto impacto a la biodiversidad: Prioridades en México; IMTA-CONABIO-GECI-Arid America-The Nature Conservancy: Jiutepec, Mexico, 2007; ISBN 978-968-5536-92-9.

36. Marshall, V.M.; Lewis, M.M.; Ostendorf, B. Buffel grass (Cenchrus ciliaris) as an invader and threat to biodiversity in arid environments: A review. J. Arid Environ. 2012, 78, 1-12. [CrossRef]

37. Vibrans, H. Asclepias curassavica L. Malezas de México. Available online: http://www.conabio.gob.mx/malezasdemexico/ asclepiadaceae/asclepias-curassavica/fichas/ficha.htm (accessed on 8 September 2021).

38. Tietze, H.S.E.; Joshi, J.; Pugnaire, F.I.; de Sá Dechoum, M. Seed germination and seedling establishment of an invasive tropical tree species under different climate change scenarios. Austral Ecol. 2019, 44, 1351-1358. [CrossRef]

39. Hao, J.H.; Lv, S.S.; Bhattacharya, S.; Fu, J.G. Germination response of four alien congeneric Amaranthus species to environmental factors. PLoS ONE 2017, 12, e0170297. [CrossRef] [PubMed]

40. Vibrans, H. Datura stramonium L. Malezas de México. Available online: http://www.conabio.gob.mx/malezasdemexico/ solanaceae/datura-stramonium/fichas / ficha.htm (accessed on 10 September 2021).

41. Torres-Colín, L.; Duno-De Stefano, R.; Gómez-Hinostrosa, C. Los géneros Alysicarpus y Desmodium (Fabaceae) en la península de Yucatán, México. Rev. Mex. Biodivers. 2011, 82, 1087-1097. [CrossRef]

42. Vibrans, H. Eragrostis prolifera (Sw.) Steud. Available online: https:/ /www.gbif.org/es/species/2705328 (accessed on 20 August 2021).

43. CONABIO Pithecelobium Dulce. Available online: http://www.conabio.gob.mx/conocimiento/info_especies/arboles/doctos/ 45-legum38m.pdf (accessed on 20 August 2021).

44. CABDirect. Available online: https:/ / www.cabdirect.org/ (accessed on 20 August 2021).

45. Vibrans, H. Solanum Erianthum D. Don. Malezas de México. Available online: http://www.conabio.gob.mx/malezasdemexico/ solanaceae/solanum-erianthum/fichas/ficha.htm (accessed on 14 September 2021).

46. dos Santos, J.M.A.; Carneiro, L.T.; Martins, C.F. Are native nectar robbers against the alien? Effects of floral larceny on the reproductive success of the invasive yellow bells (Tecoma stans, Bignoniaceae). Acta Oecol. 2020, 105, 103547. [CrossRef]

47. De Roy, K.; Marzorati, M.; Negroni, A.; Thas, O.; Balloi, A.; Fava, F.; Verstraete, W.; Daffonchio, D.; Boon, N. Environmental conditions and community evenness determine the outcome of biological invasion. Nat. Commun. 2013, 4, 1383-1385. [CrossRef] [PubMed]

48. Rolim, R.G.; de Ferreira, P.M.A.; Schneider, A.A.; Overbeck, G.E. How much do we know about distribution and ecology of naturalized and invasive alien plant species? A case study from subtropical southern Brazil. Biol. Invasions 2015, 17, 1497-1518. [CrossRef]

49. Von Holle, B.; Simberloff, D. Ecological resistance to biological invasion overwhelmed by propagule pressure. Ecology 2005, 86, 3212-3218. [CrossRef] 
50. Von Holle, B.; Delcourt, H.R.; Simberloff, D. The importance of biological inertia in plant community resistance to invasion. J. Veg. Sci. 2003, 14, 425-432. [CrossRef]

51. Dawson, W.; Moser, D.; van Kleunen, M.; Kreft, H.; Pergl, J.; Pyšek, P.; Weigelt, P.; Winter, M.; Lenzner, B.; Blackburn, T.M.; et al. Global hotspots and correlates of alien species richness across taxonomic groups. Nat. Ecol. Evol. 2017, 1, 186. [CrossRef]

52. Gao, L.; Hou, B.; Cai, M.L.; Zhai, J.J.; Li, W.H.; Peng, C.L. General laws of biological invasion based on the sampling of invasive plants in China and the United States. Glob. Ecol. Conserv. 2018, 16, e00448. [CrossRef]

53. Nuñez, M.A.; Pauchard, A. Biological invasions in developing and developed countries: Does one model fit all? Biol. Invasions 2010, 12, 707-714. [CrossRef]

54. Frehse, F.d.A.; Braga, R.R.; Nocera, G.A.; Vitule, J.R.S. Non-native species and invasion biology in a megadiverse country: Scientometric analysis and ecological interactions in Brazil. Biol. Invasions 2016, 18, 3713-3725. [CrossRef]

55. McGeoch, M.A.; Butchart, S.H.M.; Spear, D.; Marais, E.; Kleynhans, E.J.; Symes, A.; Chanson, J.; Hoffmann, M. Global indicators of biological invasion: Species numbers, biodiversity impact and policy responses. Divers. Distrib. 2010, 16, 95-108. [CrossRef]

56. Lin, W.; Zhou, G.; Cheng, X.; Xu, R. Fast economic development accelerates biological invasions in China. PLoS ONE 2007, 2, e1208. [CrossRef] [PubMed]

57. Lövei, G.L.; Lewinsohn, T.M.; Dirzo, R.; Elhassan, E.F.M.; Ezcurra, E.; Freire, C.A.d.O.; Gui, F.-R.; Halley, J.M.; Tibazarwa, J.M.; Jiang, M.-X.; et al. Megadiverse developing countries face huge risks from invasives. Trends Ecol. Evol. 2012, 27, 2-3. [CrossRef] [PubMed]

58. Espejel, I. A phytogeographical analysis of coastal vegetation in the Yucatan Peninsula. J. Biogeogr. 1987, 14, 499-519. [CrossRef]

59. Moreno-Casasola, P.; Castillo, S.; Martínez, M.L. Flora de las playas y los ambientes arenosos (dunas) de las costas. In La biodiversidad en Veracruz: Estudio de Estado; CONABIO: Mexico City, Mexico, 2011; pp. 229-238.

60. Pérez-Navarro, J.J. La Vegetación de Ambientes Costeros de la Región de los Cabos, Baja California sur: Aspectos Florísticos y Ecológicos, ENEP-Iztacala. Ph.D. Thesis, Universidad Nacional Autónoma de México, Mexico City, Mexico, 1995.

61. van Kleunen, M.; Dawson, W.; Essl, F.; Pergl, J.; Winter, M.; Weber, E.; Kreft, H.; Weigelt, P.; Kartesz, J.; Nishino, M.; et al. Global exchange and accumulation of non-native plants. Nature 2015, 525, 100-103. [CrossRef] [PubMed]

62. Nathan, R.; Muller-Landau, H.C. Spatial patterns of seed dispersal, their determinants and consequences for recruitment. Trends Ecol. Evol. 2000, 15, 278-285. [CrossRef]

63. Chapman, D.S.; Scalone, R.; Štefanić, E.; Bullock, J.M. Mechanistic species distribution modeling reveals a niche shift during invasion. Ecology 2017, 98, 1671-1680. [CrossRef] [PubMed]

64. Gallego-Fernández, J.B.; Martínez, M.L.; García-Franco, J.G.; Zunzunegui, M. Multiple seed dispersal modes of an invasive plant species on coastal dunes. Biol. Invasions 2021, 23, 111-127. [CrossRef] 